\title{
Zoledronic acid treatment impairs protein geranyl-geranylation for biological effects in prostatic cells
}

\author{
M Goffinet $^{1}$, M Thoulouzan ${ }^{1}$, A Pradines ${ }^{1}$, I Lajoie-Mazenc ${ }^{1}$, \\ Carolyn Weinbaum² ${ }^{2}$ JC Faye ${ }^{* 1}$ and S Séronie-Vivien ${ }^{1}$
}

\author{
Address: ${ }^{1}$ Inserm U563, Centre de Physiopathologie de Toulouse Purpan, Département "Innovation Thérapeutique et Oncologie Moléculaire", \\ Institut Claudius Regaud, Toulouse, France and '2Duke University, Medical Center Department of Pharmacology \& Cancer Biology, Durham, NC, \\ USA \\ Email: M Goffinet - goffinet@icr.fnclcc.fr; M Thoulouzan - thoulouzan@icr.fnclcc.fr; A Pradines - Pradines@icr.fnclcc.fr; I Lajoie- \\ Mazenc - Lajoie@icr.fnclcc.fr; Carolyn Weinbaum - weinb006@mc.duke.edu; JC Faye* - faye@icr.fnclcc.fr; S Séronie- \\ Vivien - seronie@icr.fnclcc.fr \\ * Corresponding author
}

Published: 15 March 2006

BMC Cancer2006, 6:60 doi:10.1/86/147/-2407-6-60
Received: 02 February 2006

Accepted: 15 March 2006

This article is available from: http://www.biomedcentral.com/147I-2407/6/60

(c) 2006Goffinet et al; licensee BioMed Central Ltd.

This is an Open Access article distributed under the terms of the Creative Commons Attribution License (http://creativecommons.org/licenses/by/2.0), which permits unrestricted use, distribution, and reproduction in any medium, provided the original work is properly cited.

\begin{abstract}
Background: Nitrogen-containing bisphosphonates (N-BPs) have been designed to inhibit osteoclast-mediated bone resorption. However, it is now accepted that part of their anti-tumor activities is related to interference with the mevalonate pathway.

Methods: We investigated the effects of zoledronic acid (ZOL), on cell proliferation and protein isoprenylation in two tumoral (LnCAP, PC-3,), and one normal established (PNTI-A) prostatic cell line. To assess if inhibition of geranyl-geranylation by ZOL impairs the biological activity of RhoA GTPase, we studied the LPA-induced formation of stress fibers. The inhibitory effect of ZOL on geranyl geranyl transferase I was checked biochemically. Activity of ZOL on cholesterol biosynthesis was determined by measuring the incorporation of ${ }^{14} \mathrm{C}$ mevalonate in cholesterol.

Results: ZOL induced dose-dependent inhibition of proliferation of all the three cell lines although it appeared more efficient on the untransformed PNTIA. Whatever the cell line, $20 \mu \mathrm{M}$ ZOLinduced inhibition was reversed by geranyl-geraniol (GGOH) but neither by farnesol nor mevalonate. After 48 hours treatment of cells with $20 \mu \mathrm{M}$ ZOL, geranyl-geranylation of Rap IA was abolished whereas farnesylation of HDJ-2 was unaffected. Inhibition of Rap IA geranyl-geranylation by $\mathrm{ZOL}$ was rescued by $\mathrm{GGOH}$ and not by $\mathrm{FOH}$. Indeed, as observed with treatment by a geranylgeranyl transferase inhibitor, treatment of PNTI-A cells with $20 \mu \mathrm{M}$ ZOL prevented the LPAinduced formation of stress fibers. We checked that in vitro ZOL did not inhibit geranyl-geranyltransferase I. ZOL strongly inhibited cholesterol biosynthesis up to 24 hours but at 48 hours $90 \%$ of this biosynthesis was rescued.

Conclusion: Although zoledronic acid is currently the most efficient bisphosphonate in metastatic prostate cancer management, its mechanism of action in prostatic cells remains unclear. We suggest in this work that although in first intention ZOL inhibits FPPsynthase its main biological actitivity is directed against protein Geranylgeranylation.
\end{abstract}




\section{Background}

Bisphosphonates (BPs) have been used in oncological practice for many years to reduce skeletal complications and pain especially during myeloma and the metastatic phase of breast and prostate cancers. For many years their specific bone targeting suggested that the main mechanism of action of BPs was inhibition of bone resorption by direct effects on osteoclasts or other bone cells in the immediate microenvironment of osteoclasts[1]. The lategeneration BPs have a nitrogen-containing aliphatic side chain (pamidronate, alendronate, ibandronate) or heterocyclic ring (zoledronate). Their anti-resorptive potency is up to 1000 -fold greater than that of non-amino BPs and they exert their cellular effects by interference with the mevalonate (MVA) pathway [2]. Many studies have investigated the nature of the enzymatic targets of N-BPs within the MVA pathway. In vitro, squalene synthase activity was shown to be affected by some N-BPs but neither by pamidronate nor alendronate[3]. More recently, farnesylpyrophosphate (FPP) synthase was proposed as the main enzymatic target of alendronate, risedronate, ibandronate, and pamidronate in vitro [4-6]. Some authors suggested that isopentenyl (IPP) isomerase could also be inhibited by novel N-BPs $[4,5]$. In vivo, some studies confirmed the hypothesis of an inhibition of FPP synthase

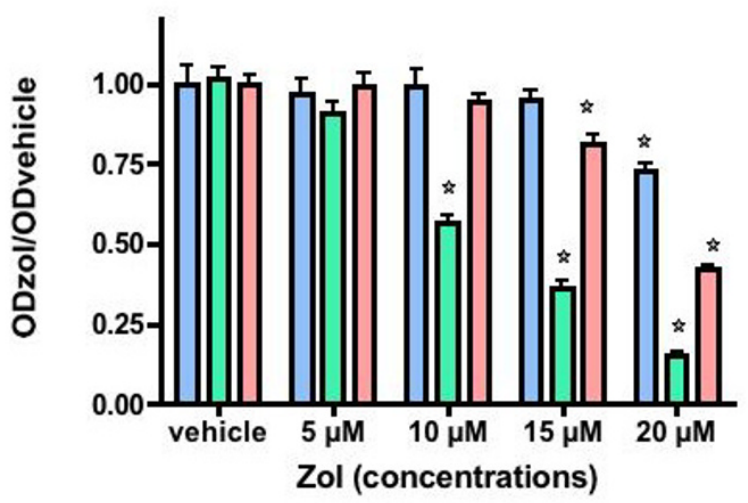

Figure I

Effect of zoledronate on proliferation of PC-3, PNTI$A$ and LNCaP. At D0, the cells were seeded into 96-well plates to obtain $80 \%$ confluence at D5 in control wells. At $D I$ and D3, cells were treated by vehicle or increasing doses of zoledronate (ZOL: 5, 10, I5, $20 \mu \mathrm{M}$ ). At D5, the cells were fixed with TCA and stained with $0.4 \%$ sulforhodamine. Staining intensity was quantified at $540 \mathrm{~nm}$. Results are expressed as the ratio $O D_{\text {treatedcells }} / O D_{\text {untreated }}$ of three independent assays each performed six times. Error bars indicate inter-assay mean \pm ISD. * indicates a significant difference versus non-treated cells $(P<0.01)$. PC3 PNTIA LNCaP because apoptosis [7-9] and caspase activation [7] induced by several N-BPs were reversed by addition of FPP and GGPP or of cell-permeable analogs, farnesol (FOH) and geranyl-geraniol (GGOH). Conversely, recent in vivo studies suggested that the inhibition of the mevalonate pathway by N-BPs lies downstream the FPP synthesis step; indeed, several cellular effects of N-BPs such as inhibition of osteoclast formation[10], inhibition of ovarian cancer cell migration [11] or inhibition of breast cancer cell invasion [12] were reversed only by GGOH but not by FOH. Whatever the enzymatic target(s) of N-BPs most previous reports agree to suggest that the action of N-BPs results in the impairment of protein isoprenylation in osteoclasts or bone explants $[4,5,8,10,13,14]$ as well as in tumoral cell lines $[9,12,15-17]$. It remains unclear whether protein farnesylation and geranyl-geranylation are equally affected by N-BPs. Some recent data suggest that geranyl-geranylation, especially of Rho GTPases, may be the main target of

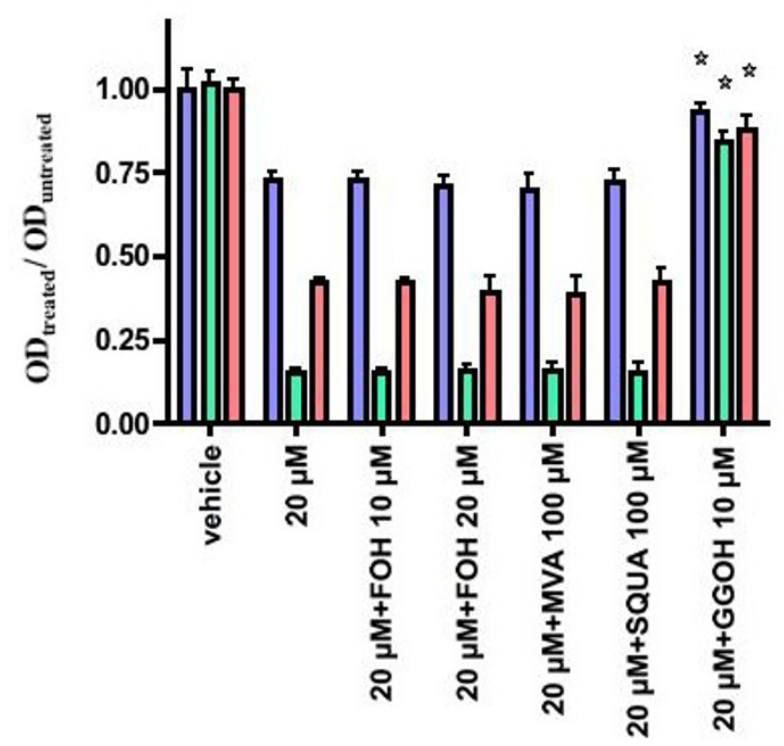

Figure 2

Effect of mevalonate-derived products on $20 \mu \mathrm{M}$ zoledronate-induced inhibition of prostatic cell proliferation. At D0, cells were seeded into 96-well plates to obtain $80 \%$ confluence at D5 in control wells. At DI, and D3, cells were treated by vehicle or $20 \mu \mathrm{M}$ zoledronate (ZOL) in the presence or absence of intermediates of the mevalonate pathway $(\mathrm{GGOH}=$ geranyl-geraniol; $\mathrm{MVA}=$ mevalonate; $\mathrm{FOH}=$ farnesol; SQUA = squalene) at the indicated doses. Results are are expressed as the ratio $O D_{\text {treated cells }} / O D_{\text {un- }}$ treated of three independent assays each performed six times. Error bars indicate inter-assay mean \pm I SD. * indicates a significant difference versus ZOL-treated cells $(\mathrm{p}<0.0 \mathrm{I})$.

PC-3 PNTIA LNCaP 
their anti-invasive effect $[11,12]$ although their apoptotic effect may be related to the inhibition of Ras farnesylation $[16,17]$.

In prostate tumoral cells, few studies have investigated the cellular or molecular effects of N-BPs, while zoledronate (ZOL) and pamidronate (PAM) are widely used to prevent skeletal complications of prostate cancer and of androgen deprivation therapy $[18,19]$. After the report of the inhibition of prostate carcinoma cell invasion by several N-BPs, including ZOL [20], PAM and ZOL were shown to inhibit growth in three widely used prostatic cell lines, PC-3, DU145 and LNCaP [21]. The anti-tumor effect of alendronate, ZOL and PAM was correlated to their inhibition of the MWA pathway in prostate cells [15,17], favoring the hypothesis of an inhibition of FPP synthesis, protein geranyl-geranylation was not assessed although GGOH appeared more effective than FOH to rescue ZOL-induced apoptosis.

In the present work, we investigated i) the effect of ZOL and MVA-derived metabolites on tumoral and normal immortalized prostatic cell line proliferation; ii) the modification by ZOL of the prenylation status of farnesylated (HDJ-2) and geranyl-geranylated (Rap1A) proteins in prostatic cells; iii) the impact of ZOL on the biological activity of a geranyl-geranylated protein, RhoA; vi) the effect of ZOL on cholesterol biosynthesis.

\section{Methods}

\section{Chemicals and materials}

All material for cell culture was from Dutcher (Brumath, France). Growth media were purchased from Cambrex Bio Science (Verviers, Belgium) and fetal calf serum (FCS) from Invitrogen (Cergy-Pontoise, France). Zoledronic acid [hydrated disodium salt of 2-(imidazol-1-yl)hydroxyl-ethylene-1,1-bisphosphonic acid)] was supplied by Novartis Pharma AG (Basel, Switzerland). Stock solutions ( $4 \mathrm{mM}$ ) were prepared in phosphate buffered saline (PBS) and aliquots were stored at $-20^{\circ} \mathrm{C}$ to be diluted in culture medium prior to experiments. Peptidomimetic prenyl-transferase inhibitors FTI 277 and GGTI 298 $[22,23]$ were a generous gift from Pr S. Sebti (Tampa, Florida). Stock solutions $(100 \mathrm{mM})$ were prepared in DMSO$10 \mathrm{mM}$ DTT and aliquots were stored at $-20^{\circ} \mathrm{C}$ to be diluted in culture medium prior to experiments. Y27632 was purchased from Calbiochem (La Jolla, California). Mevalonate $($ stock $=$ MVA $200 \mathrm{mM}$ ), trans-transfarnesol (FOH; stock solutions $100 \mathrm{mM}$ in ethanol, stored at $20^{\circ} \mathrm{C}$ ), geranyl-geraniol (GGOH; stock solutions $100 \mathrm{mM}$ in ethanol stored at $-20^{\circ} \mathrm{C}$ ), squalene (stock solutions 100 $\mathrm{mM}$ in ethanol stored at $\left.-20^{\circ} \mathrm{C} \mathrm{FOH}\right)$, Cholesterol, L- $\alpha$ lysophosphatidic acid (LPA) and paraformaldehyde (PFA) were purchased from Sigma Aldrich (St Quentin
Fallavier, France). $\left[{ }^{14} \mathrm{C}\right]$-mevalolactone $(56 \mathrm{Ci} / \mathrm{mmol}$. specific activity) was from Perkin-Elmer.

\section{Prostatic cell lines}

LNCaP cells are prostatic tumoral human cells expressing an active but mutated (T877A) androgen receptor. Under androgenic stimulation, these cells produce prostate-specific antigen (PSA). PC-3 are prostatic tumoral human cells, which are non-responsive to androgenic stimulation. The PNT1-A cell line was developed by Cussenot et al. [24]. The cells are normal epithelial cells immortalized by SV-40. They express the wild-type androgen receptor but, under androgenic stimulation in vitro, they do not secrete PSA into the culture medium. The three cell lines were purchased from the European Collection of Cell Culture (PC-3: \# 90112714; LNCaP clone FCG: \# 89110211; PNT1A: \#95012614).

Prostatic cell lines were routinely grown either in RPMI 7\% FCS (PC-3 and PNT1-A) or in RPMI 10\% FCS supplemented by $10 \mathrm{mM}$ Hepes and $1 \mathrm{mM}$ sodium pyruvate (LNCaP). All cells were incubated at $37^{\circ} \mathrm{C}$ in a humidified $5 \% \mathrm{CO}_{2}$ incubator.

\section{Proliferation colorimetric assay}

Proliferation was assessed by a colorimetric assay with sulforhodamine as described by Skehan [25]. Cells were seeded in 96-well microtiter plates to finally obtain $80 \%$ confluence in control wells. At the end of the treatment period, the cells were fixed with TCA $\left(1 \mathrm{~h}, 4^{\circ} \mathrm{C}\right)$ and then stained with $0.4 \%$ sulforhodamine. After four washes with $1 \%$ acetic acid to remove unbound dye, the plates were dried and protein-bound dye was extracted with Tris $(10 \mathrm{mM}, \mathrm{pH}=10.5)$. Coloration was quantified at 540 $\mathrm{nm}$ in a microtiter plate (Multiskan ${ }^{\circledR}$ Multisoft, Labsystems)

\section{Prenylation status analysis}

Cells were scraped off then lysed with $150 \mu \mathrm{L}$ of lysis buffer [20 mM Tris-HCl, $100 \mathrm{mM} \mathrm{NaCl}, 1 \%$ Triton X-100, $10 \mathrm{mM} \mathrm{MgCl} 2,5 \mathrm{mM}$ EDTA, $20 \mathrm{mM} \mathrm{NaF}, 10 \mathrm{mM}$ PNPP, $2 \mathrm{mM} \mathrm{Na}$ orthovanadate, and a cocktail of protease inhibitors (Sigma, France, final dilution 1/100). Proteins were quantified in cellular extracts by a Bradford assay. Five to forty $\mu$ g of cleared protein extracts were separated on a $12.5 \%$ SDS-polyacrylamide gel and then transferred to a Hybond-P polyvinyldifluoride membrane (Amersham Biosciences). After pre-incubation with TBST ( $25 \mathrm{mM}$ Tris, $140 \mathrm{mM} \mathrm{NaCl}, 0.1 \%$ Tween 20, pH 8) supplemented with $5 \%$ fat-free milk, the membranes were incubated overnight at $4{ }^{\circ} \mathrm{C}$ with the primary antibody diluted in TBST 1 $\%$ milk. After three washes with TBST, the membranes were incubated for 1 hour at room temperature with the secondary antibody labeled by peroxidase. The antibody was visualized using the ECL Plus system (Amersham Bio- 


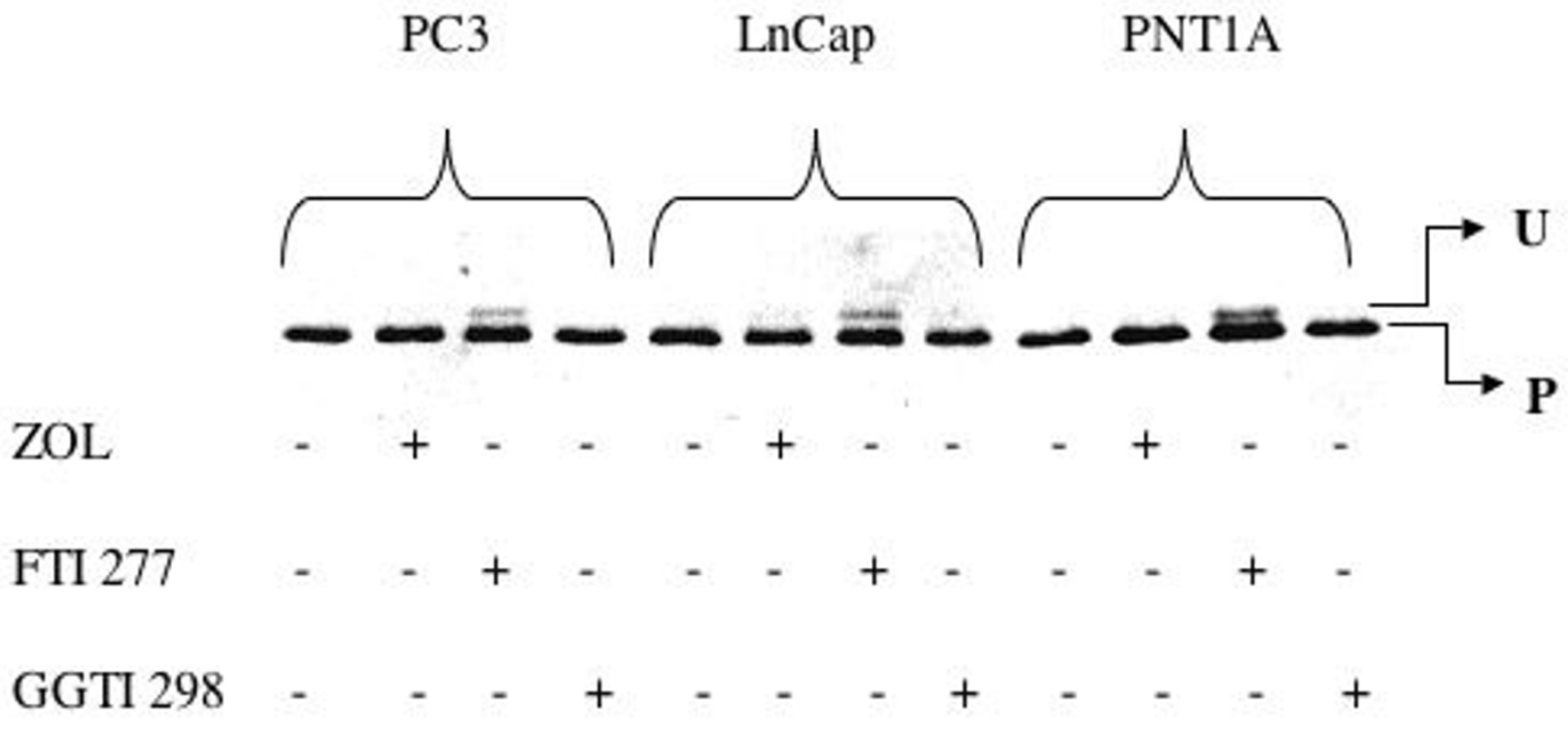

Figure 3

Effect of zoledronate on farnesylation status of HDJ2. Prostatic cells where treated for $48 \mathrm{~h}$ with ZOL $(20 \mu \mathrm{M})$, lysed in hot $\left(90^{\circ} \mathrm{C}\right) \mathrm{SDS}(\mathrm{I} \%)$ and analyzed by Western blot.

sciences) and luminescence quantified with Phophorimager ${ }^{\circledR}$ (Molecular Dynamics).

The following primary antibodies were used: anti-HDJ2 Ab-1 mouse monoclonal antibody (Interchim; clone KA2A5.6, diluted 1/10000), anti-prenylated Rap1A C17 goat polyclonal antibody (TEBU; ref SC-1482, diluted 1/ 2000), anti-total Rap1A-Krev1 rabbit polyclonal antibody (TEBU; ref SC-65, diluted1/1000). The following peroxidase-labeled secondary antibodies were used, all diluted 1/10000: anti-mouse (Biorad, ref 170-6516) anti-goat (Santa Cruz, ref sc-2033) or anti-rabbit (Biorad, ref 1706515).

\section{Visualization of actin cytoskeleton by fluorescence microscopy}

At day 0 (D0), PNT1-A cells were seeded onto glass coverslips in 6-well plates to obtain $60 \%$ confluence on day 3 (D3). On day 1 (D1), the cells were serum-starved until treatment on D3. After exposure to different drugs and then after stimulation by LPA $(20 \mu \mathrm{M}, 5$ hours on D3), the cells were fixed with 3\% paraformaldehyde/PBS for 20 minutes and then permeabilized with $0.1 \%$ Triton- X100/PBS for 5 minutes. To visualize the actin fibers, the coverslips were incubated with tetramethylrhodamine isothiocyanate-labeled phalloidin (Molecular Probes) for 30 minutes at room temperature. The cells were viewed on a Zeiss Axiophot microscope and pictures taken with a Princeton camera.

In vitro farnesyl-transferase (FTase) and geranyl-geranyltransferase I (GGTase I) activity measurement

To investigate the putative inhibitory effect of ZOL on prenyl-transferase activity, in vitro prenylation assays were performed. As substrate proteins, we used bacterially expressed wild-type H-Ras protein for FTase assay and CVLL-H-Ras mutant protein (geranyl-geranylated form) for GGTase I assay. $1 \mu \mathrm{M}$ substrate proteins were incubated with $\left[{ }^{3} \mathrm{H}\right]$-prenyl pyrophosphate $(0.25 \mu \mathrm{M}$ final concentration, specific activity $8-10 \mathrm{Ci} / \mathrm{mmol}$, American Radiolabeled Chemicals) and either recombinant FTase or recombinant GGTase I (50 ng) in a reaction medium containing $50 \mathrm{mM}$ Tris, $\mathrm{pH}$ 7.7, $20 \mathrm{mM} \mathrm{KCl}, 10 \mathrm{mM}$ $\mathrm{MgCl}_{2}, 2 \mathrm{mM}$ DTT, and $5 \mu \mathrm{M} \mathrm{ZnCl}_{2}$. The reaction volume was $50 \mu \mathrm{l}$. Reactions proceeded for $10 \mathrm{~min}$ at $30^{\circ} \mathrm{C}$ and were stopped by the addition of $0.5 \mathrm{ml}$ of $4 \% \mathrm{SDS}$. Total protein was precipitated by the addition of $0.5 \mathrm{~mL}$ of $30 \%$ trichloroacetic acid. After $20 \mathrm{~min}$, samples were filtered through 25-mm glass fiber filters (Schleicher \& Schuell), which bound the prenylated protein leaving unprenylated protein and excess prenyl groups to go through the filter. Reaction tubes were washed with $2 \times 2 \mathrm{~mL}$ of $4 \%$ SDS plus $6 \%$ trichloroacetic acid, and the washes were added to the filters. Bound protein was washed with a further $4 \mathrm{~mL}$ of 


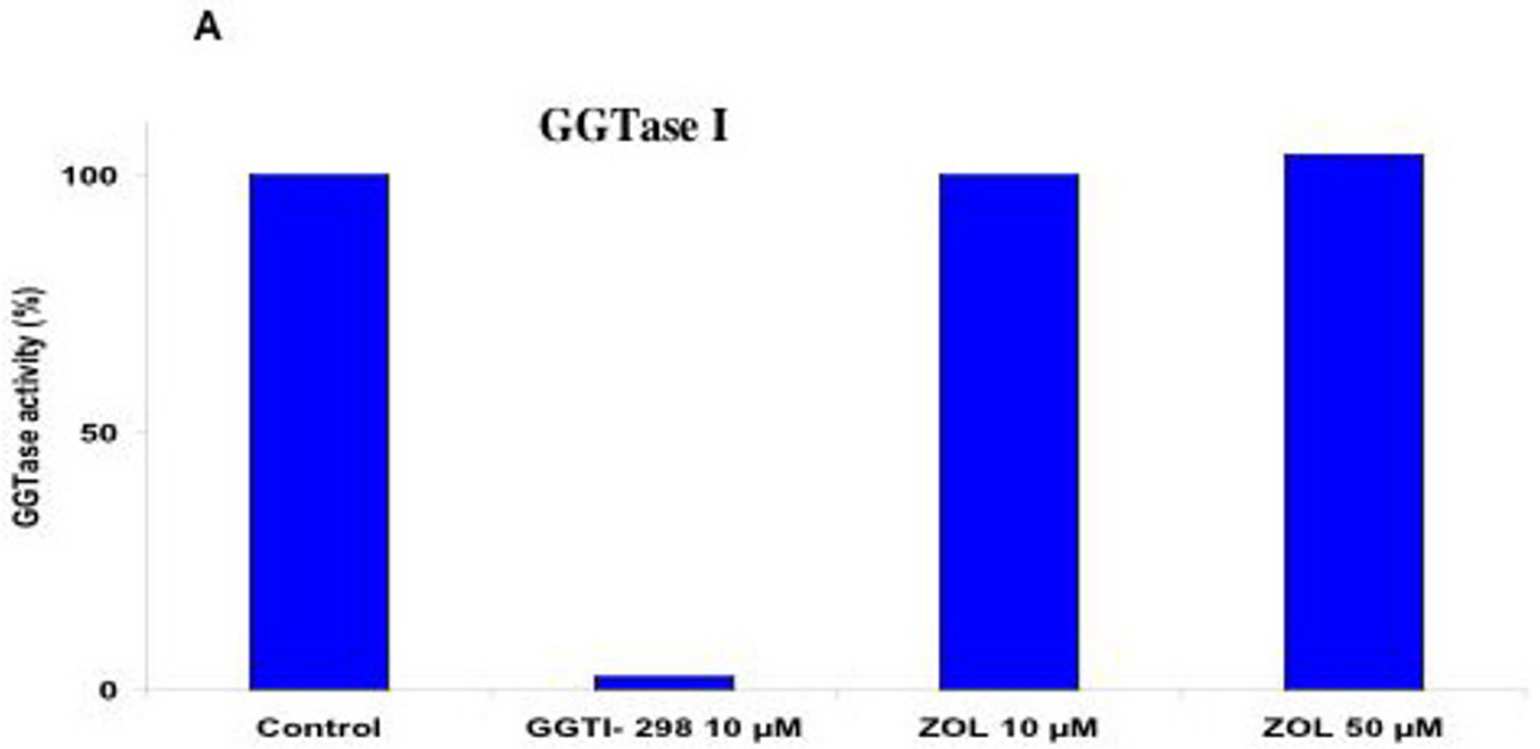

B

\begin{tabular}{|c|c|}
\hline CTL & ZOL \\
\hline
\end{tabular}

unprenylated Rap1A

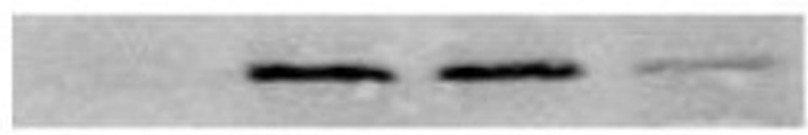

Total Rap1A

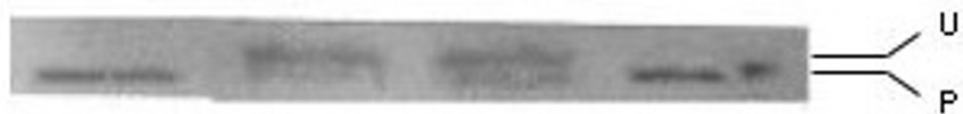

\section{Figure 4}

Effect of zoledronate on GGPP/GGOH incorporation into proteins in vitro (A) and in vivo (B). A: Geranyl-geranyl transferase I (GGTase I) was quantified using an in vitro test based on $\left[{ }^{3} \mathrm{H}\right]$-prenyl pyrophosphate $(0.5 \mu \mathrm{M}, 8-10 \mathrm{Ci} / \mathrm{mmol})$ incorporation into a mutant form of $\mathrm{H}$-ras with a geranyl-geranylation CAXX box. The level of prenylation is expressed as a percentage of maximum incorporation of $\left[{ }^{3} \mathrm{H}\right]$-prenyl, as determined by allowing the uninhibited reaction to go to completion. B: Western-blot analysis; PC-3 cells are treated by vehicle, ZOL $20 \mu \mathrm{M}$; ZOL $20 \mu \mathrm{M}+\mathrm{FOH}$ I0 $\mu \mathrm{M}$; ZOL $20 \mu \mathrm{M}+\mathrm{GGOH}$ I0 $\mu \mathrm{M}$.

$4 \%$ SDS/ $6 \%$ trichloroacetic acid and then $3 \times 2 \mathrm{~mL} 6 \%$ trichloroacetic acid. After drying, radioactivity bound to the filters was counted in a scintillation counter. Negative controls were also performed without protein substrate or using enzymes that were previously inactivated by incubation for $5 \mathrm{~min}$ at $90^{\circ} \mathrm{C}$. Each substrate protein was reacted under standard conditions with vehicle, specific transferase inhibitor or ZOL. The level of prenylation was expressed as a percentage of maximum incorporation of $\left[{ }^{3} \mathrm{H}\right]$-prenyl for each substrate, as determined by allowing the uninhibited reaction to go to completion.

\section{$\left[{ }^{14} \mathrm{C}\right]$-Cholesterol biosynthesis in PC3 cells}

The experiment was conducted as described by Awad [26]. Briefly, PC3 cells were seeded in 6-well plates and treated with ZOL for 2, 22, 46 hours and $\left[{ }^{14} \mathrm{C}\right]$-mevalolactone $(2.25 \mu \mathrm{Ci} / \mathrm{ml})$ was added to the medium for 2 hours more, then the medium was removed, the cells washed twice with PBS, and treated by $1 \mathrm{ml}$ of $\mathrm{NaOH}(2 \mathrm{M})$. The mixture was incubated at $37^{\circ} \mathrm{C}$ for $30 \mathrm{~min}$. and then 0.5 $\mathrm{ml}$ of methanol containing $100 \mu \mathrm{g}$ of non-radioactive cholesterol were added. Saponification took place at $70^{\circ} \mathrm{C}$ for 1 hour and unsaponified lipids were hexane extracted 


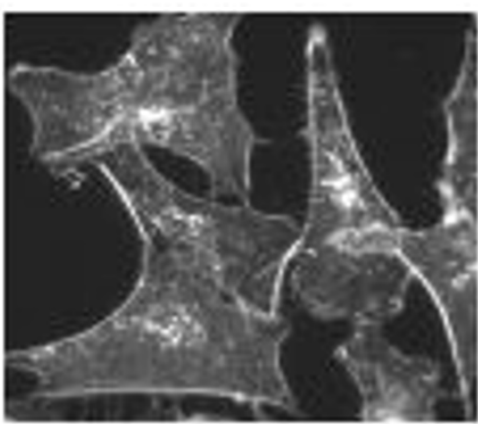

A: no LPA no drug

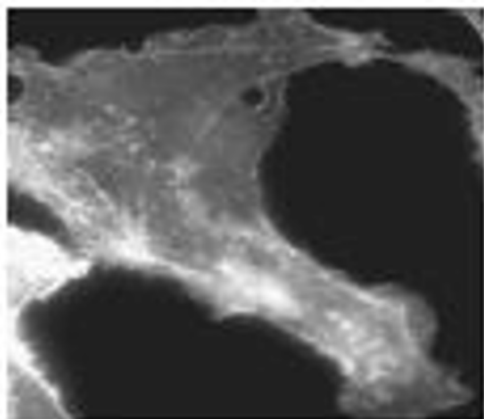

C: $20 \mu \mathrm{M} \mathrm{LPA}, 5 \mathrm{~h}$

$10 \mu \mathrm{M} \mathrm{Y} 27632,10 \mathrm{~min}$
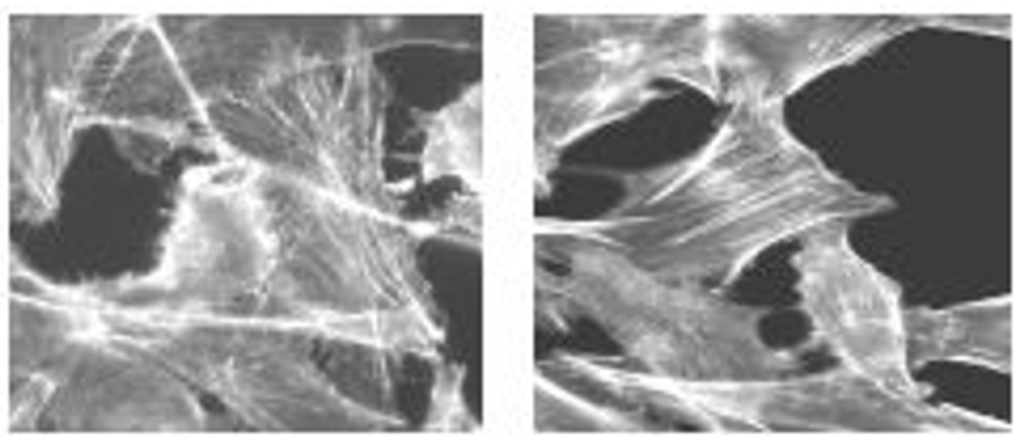

$\mathrm{B}_{1}$ and $\mathrm{B}_{2}: 20 \mu \mathrm{M}$ LPA 5 h, no drugs

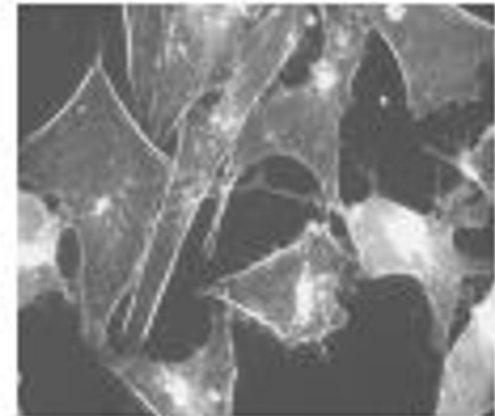

D: $20 \mu \mathrm{M}$ LPA, $5 \mathrm{~h}$

$10 \mu \mathrm{M}$ GGTI-298,24h

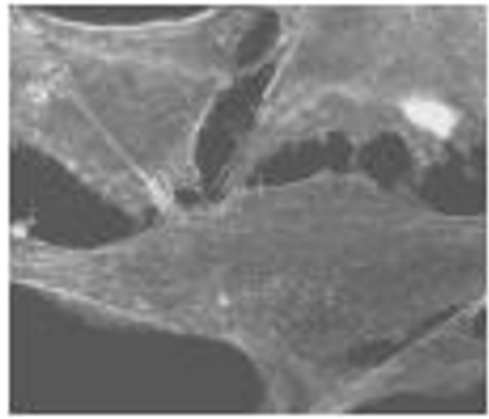

$\mathrm{E}: 20 \mu \mathrm{M} \mathrm{LPA}, 5 \mathrm{~h}$

\section{Figure 5}

Effect of zoledronate on LPA-induced stress fiber induction, a cellular effect dependent on RhoA geranylgeranylation. On $D_{0}$, PNTI-A cells were seeded onto glass coverslips in 6 -well plates to obtain $60 \%$ confluence on $D_{3}$. On $D_{1}$, the cells were serum-starved till fixation on $D_{3}$. After treatment by the indicated drugs then stimulation by LPA ( $20 \mu M, 5$ hours on $D_{3}$ ), actin fibers were visualized by tetramethylrhodamine isothiocyanate-labeled phalloidin. Cells are viewed on a Zeiss Axiophot microscope $(X 630)$, and pictures are taken with a Princeton camera.

three times. After drying (under argon) the pellets were dissolved in chloroform and separated by thin layer chromatography (silica gel F/ethyl acetate). [ $\left.{ }^{14} \mathrm{C}\right]$-Cholesterol was revealed and quantified by autoradiography with Phophorimager $^{\circledR}$ (Molecular Dynamics).

\section{Results}

Zoledronic acid inhibits proliferation of LNCap, PC-3 and PNTI-A cells

The effect of ZOL on cell growth was assessed in the three prostatic cell lines: the cells were treated from D1 to D5 with ZOL from 5 to $20 \mu \mathrm{M}$. The ratio of proliferation ver- sus control wells was assessed by a colorimetric sulforhodamine assay. The results are shown in figure $1 . \mathrm{ZOL}$ inhibited the proliferation of the three cell lines dosedependently. The non-tumoral cell line PNT1-A was affected most $\left(\mathrm{IC}_{50}=11 \mu \mathrm{M}\right)$. PC-3 cells displayed an intermediate sensitivity $\left(\mathrm{IC}_{50}=18 \mu \mathrm{M}\right)$ and the $\mathrm{LNCaP}$ cells appeared to be the most resistant $\left(\mathrm{IC}_{50}>20 \mu \mathrm{M}\right)$. These results agree with those previously obtained by others for growth [21,27] or viability [15] of DU145, PC-3 and $\mathrm{LNCaP}$ in the presence of ZOL. Moreover the present work shows that ZOL is more effective at inhibiting the cell growth of the untransformed cell line PNT1-A. 


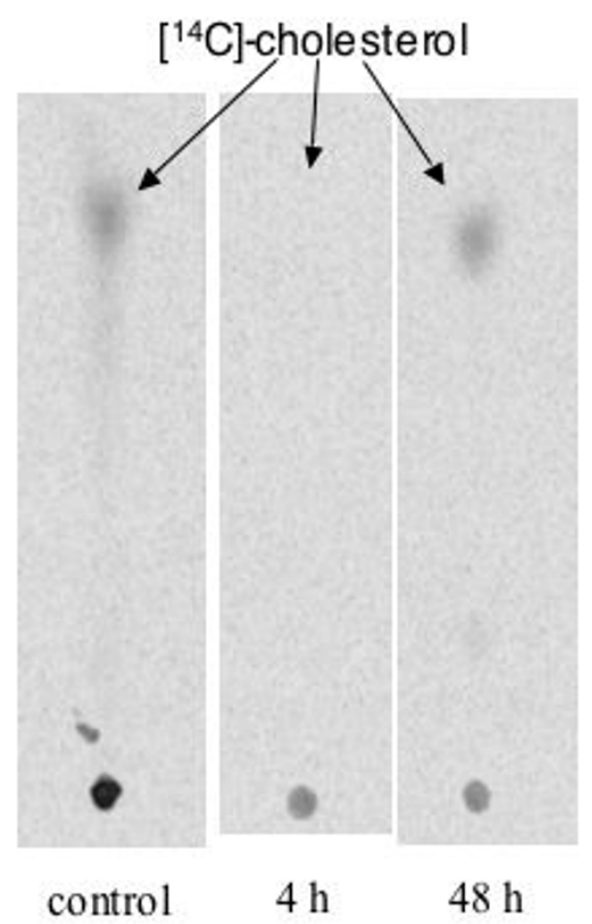

A

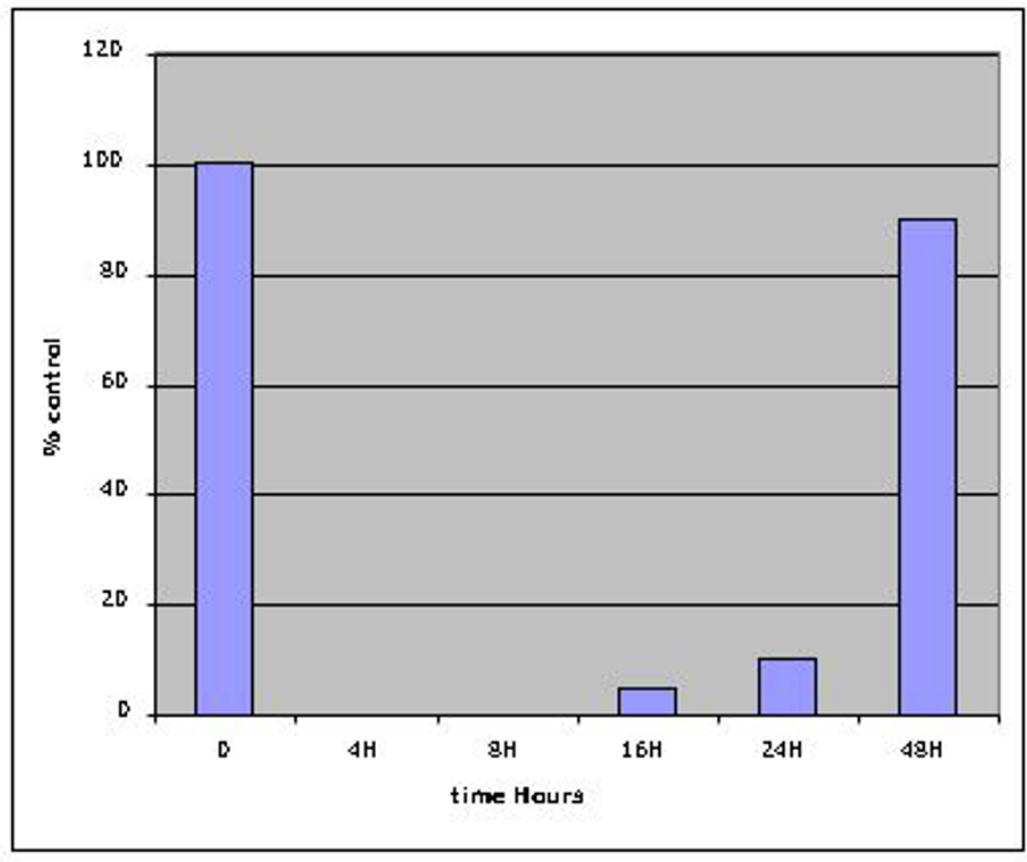

B

\section{Figure 6}

Biosynthesis of $\left[{ }^{14} \mathbf{C}\right]$-cholesterol in PC3 cells under ZOL treatments. Cells were treated with ZOL (20 $\mu$ M) for 2,22 or 46 hours and $\left[{ }^{14} \mathrm{C}\right]$-mevalolactone $(2.25 \mu \mathrm{Ci} / \mathrm{ml})$ was added to the medium for 2 hours more. Sterols were separated by thin layer chromatography (silica gel F/ethyl acetate). $\left[{ }^{14} \mathrm{C}\right]$-Cholesterol was revealed and quantified by autoradiography with Phophorimager ${ }^{\circledR}$ (Molecular Dynamics).

\section{Inhibition of proliferation by ZOL is reversed by geranyl- geraniol}

$\mathrm{N}$-BPs have been described to interfere with the mevalonate pathway. We therefore investigated if the inhibition of proliferation observed with $20 \mu \mathrm{M}$ ZOL could be reversed by metabolites of the MVA pathway: MVA (100 $\mu \mathrm{M})$, the precursor of all sterol and non-sterol isoprenoids, squalene (SQUA, $100 \mu \mathrm{M}$ ), the precursor of cyclic isoprenoids i.e. sterols, farnesol (FOH, 10 and $20 \mu \mathrm{M}$ ) and geranylgeraniol (GGOH, $10 \mu \mathrm{M})$. Unlike FPP and GGPP, free isoprenols FOH and GGOH are able to enter the cells easily [28], thus, they can be used for prenylation via a salvage pathway. Cells were seeded as previously described and treated every 48 hours with $20 \mu \mathrm{M}$ ZOL in the presence or absence of the different metabolites from D1 to D5. The results are shown in figure 2. Concerning the differential sensitivity of the three cell lines to ZOL, the results were similar to those previously obtained although a two-day longer exposure resulted in a greater cell growth inhibition with $20 \mu \mathrm{M}$ ZOL. At the concentra- tions used, none of the MVA-derived products altered the proliferation (data not shown). Moreover, neither MVA, SQUA, or FOH could reverse the inhibition of proliferation induced by $20 \mu \mathrm{M}$ ZOL. In contrast, GGOH completely rescued the proliferation of the three prostatic cell lines when added to the culture medium simultaneously with $20 \mu \mathrm{M}$ ZOL. However, the reversion of ZOL-induced inhibition of proliferation by GGOH but not by $\mathrm{FOH}$ does not agree with the biochemical target of ZOL, FPP synthase.

\section{ZOL impairs in vivo geranyl-geranylation of Rap IA without impairing farnesylation of $\mathrm{HDJ}-2$}

To investigate the effects of ZOL on farnesylation and geranyl-geranylation, we analysed i) Rap-1A, an exclusively geranyl-geranylated small GTPase involved in the regulation of signal transmission from Ras, ii) HDJ-2, an exclusively farnesylated co-chaperone protein classically used as a marker of FTase inhibition [29]. Western-blot analysis of these proteins was performed after treatment by $20 \mu \mathrm{M}$ 
ZOL, or by specific peptidomimetic inhibitors of farnesylation (FTI-277) or geranyl-geranylation (GGTI-298). The results are shown in figure 3 . Treatment by FTI 277 ( $10 \mu \mathrm{M}, 48$ hours) resulted, as expected, in the accumulation of the unfarnesylated HDJ-2 which migrates slower than the farnesylated forms. By contrast, treatments with GGTI-298 or ZOL ( $20 \mu \mathrm{M}, 48$ hours) did not modify HDJ2 farnesylation. At this point we questioned the in vivo efficacy of ZOL on the mevalonate pathway and decided to look for its effects on protein geranyl-geranylation.

\section{ZOL impairs Rap IA geranyl-geranylation by preventing GGPP production and not GGPP incorporation into the protein}

Indeed, there is a structural analogy between the bisphosphonate radical of ZOL and the pyrophosphate group of cell substrates of FTase and GGTases, respectively FPP and GGPP, and some bisphosphonate analogues of FPP were shown to inhibit FTase [30]. To challenge these two hypotheses, we tested the ability of ZOL to prevent GGPP incorporation into substrate proteins in vitro and in vivo. The results are shown in figure 4 . In vitro, we measured GGTase I activity, in the absence or presence of 10 and 50 $\mu \mathrm{M}$ ZOL. Unlike GGTI-298, which totally abolishes GGTase I activity, ZOL did not impair the enzymatic activity of GGTase I (figure 4A). We also checked that ZOL did not impair the enzymatic activity of FTase (data not shown). In vivo, we used GGOH as a surrogate for GGPP because it has been shown that GGOH can rescue Rap1A geranyl-geranylation in lovastatin-treated cells, [31]. In prostatic cells, rescue of Rap1-A geranyl-geranylation was obtained when $10 \mu \mathrm{M}$ GGOH was added simultaneously to $20 \mu \mathrm{M}$ ZOL. This recovery was observed neither after ZOL/FOH incubation, nor after GGTI/GGOH incubation (figure 4B).

So, inhibition of geranyl-geranylation by ZOL appears to result from a blockade in GGPP synthesis from FPP rather than from the inhibition of the enzymatic transfer of GGPP onto its protein substrate.

\section{ZOL impairs LPA-induced formation of stress fibers, a cellular effect dependent on RhoA geranyl-geranylation}

RhoA is a small GTPase, which is exclusively geranyl-geranylated. RhoA geranyl-geranylation is crucial for its biological activity, especially for its specific activity in the formation of stress fibers under LPA stimulation [32]. For this reason, we investigated the effect of $\mathrm{ZOL}$ on the formation of stress fibers induced by LPA stimulation. Among the three prostatic cell lines, only PNT1-A cells form an easily detectable stress fiber network in response to LPA. So, we chose this cell line for the experiment. PNT1-A cells were cultured as described above and stimulated by $25 \mu \mathrm{M}$ LPA for 5 hours. Under these conditions, numerous stress fibers appeared (fig 5B1 and 5B2). With pre-treatment by Y27832 (10 $\mu \mathrm{M}, 10 \mathrm{~min})$, a specific Rho kinase inhibitor, stress fiber induction was totally abolished (figure 5C). Similarly, when PNTI-A cells were treated with GGTI-298 $(10 \mu \mathrm{M}, 24$ hours $)$ prior to LPA stimulation, no stress fibers appeared (figure 5D). When PNT1-A cells were treated by ZOL $(20 \mu \mathrm{M}, 48$ hours) prior to LPA stimulation, stress fiber formation was also totally abolished (fig 5E). So, we suggest that inhibition of geranyl-geranylation by ZOL affects the biological activity of geranyl-geranylated proteins, as shown herein for the small GTPase RhoA.

\section{ZOL Inhibits cholesterol biosynthesis up to $\mathbf{2 4}$ hours}

Four hours treatment of PC3 cells with ZOL $20 \mu \mathrm{M}$ completely inhibited cholesterol biosynthesis (Fig 6A) suggesting that $\mathrm{ZOL}$, as previously reported, may inhibit farnesyl pyrophosphate synthase at the crossroads of the mevalonate pathway to cholesterol biosynthesis or protein isoprenylation. However, as early as 24 hours later, about $10 \%$ of the biosynthesis was rescued, reaching $90 \%$ after 48 hours (Fig 6). The same results were obtained with LnCAP and PNT-1A (data not shown).

\section{Discussion}

Although zoledronic acid is widely used in metastatic prostate cancer management, few data are available about its molecular effects in prostatic cells $[15,20,21]$. Our work shows that, in prostatic cells, ZOL impairs protein geranyl-geranylation but not farnesylation. This result contrasts with the well-documented in vitro inhibition of FPP synthase displayed by many N-BPs [4-6,33] including ZOL [33]. However, conflicting results about the FPP synthase inhibition by N-BPs have been obtained in vivo. Indeed, some studies support the inhibition of FPP synthase, impairing FPP, and consequently GGPP, production $[7-9,15,17]$, whereas other teams suggest the existence of an additional enzymatic target of N-BPs, downstream of FPP synthase $[11,12,34]$. Our results with ZOL lend further support to this latter hypothesis and corroborate two other works performed in mammary MDAMB-231 [12] and ovarian Caov-3 [16] tumoral cell lines. In the first report [12], it was shown that the anti-invasive effect of ZOL resulted from an inhibition of RhoA geranylgeranylation. In alendronate-treated Caov-3 cells, Sawada et al. showed inhibition of Rho activation through GGPP depletion and suggested that this inhibition accounted for the inhibition of LPA-induced stress fiber formation they observed. This biological effect is typically related to RhoA activity.

\section{Conclusion}

In the present work it is shown that the main biological activities of ZOL are sustained by its inhibitory effect of protein geranyl-geranylation. We show by study of cholesterol biosynthesis that this impairment of geranyl-geran- 
ylation is time-dependently related to an inhibition of FPPsynthase followed by, or concomitant with, inhibition of GGPPsynthase. In vitro studies show that this effect is not related to inhibition of GGTase I

\section{Competing interests}

The author(s) declare that they have no competing interests.

\section{Authors' contributions}

The authors' contibutions to this research are reflected in the order shown, with the exception of SSV who supervised the research and the preparation of the manuscript. MG and MT carried out cellular biology and CW enzymatic studies. AP, ILM provided helpful advices in immuno-studies, JCF and SSV conceived of the study and participated in its design and coordination. All the authors read and approved the final manuscript

\section{Acknowledgements}

We thanks C. Giamarchi for helpful discussions and technical contributions

\section{References}

I. Rogers MJ, Gordon S, Benford HL, Coxon FP, Luckman SP, Monkkonen J, Frith JC: Cellular and molecular mechanisms of action of bisphosphonates. Cancer 2000, 88:2961-2978.

2. Green JR, Clezardin P: Mechanisms of bisphosphonate effects on osteoclasts, tumor cell growth, and metastasis. Am J Clin Oncol 2002, 25:S3-9.

3. Amin D, Cornell SA, Gustafson SK, Needle SJ, Ullrich JW, Bilder GE, Perrone $\mathrm{MH}$ : Bisphosphonates used for the treatment of bone disorders inhibit squalene synthase and cholesterol biosynthesis. J Lipid Res 1992, 33:1657-1663.

4. Bergstrom JD, Bostedor RG, Masarachia PJ, Reszka AA, Rodan G: Alendronate is a specific, nanomolar inhibitor of farnesyl diphosphate synthase. Arch Biochem Biophys 2000, 373:23I-24I.

5. Thompson K, Dunford JE, Ebetino FH, Rogers MJ: Identification of a bisphosphonate that inhibits isopentenyl diphosphate isomerase and farnesyl diphosphate synthase. Biochem Biophys Res Commun 2002, 290:869-873.

6. van Beek E, Pieterman E, Cohen L, Lowik C, Papapoulos S: Farnesyl pyrophosphate synthase is the molecular target of nitrogencontaining bisphosphonates. Biochem Biophys Res Commun 1999, 264: I08-III.

7. Benford HL, Frith JC, Auriola S, Monkkonen J, Rogers MJ: Farnesol and geranylgeraniol prevent activation of caspases by aminobisphosphonates: biochemical evidence for two distinct pharmacological classes of bisphosphonate drugs. Mol Pharmacol 1999, 56:131-140.

8. Luckman SP, Hughes DE, Coxon FP, Graham R, Russell G, Rogers MJ: Nitrogen-containing bisphosphonates inhibit the mevalonate pathway and prevent post-translational prenylation of GTP-binding proteins, including Ras. J Bone Miner Res 1998, 13:58|-589.

9. Iguchi T, Miyakawa Y, Yamamoto K, Kizaki M, Ikeda Y: Nitrogencontaining bisphosphonates induce $S$-phase cell cycle arrest and apoptosis of myeloma cells by activating MAPK pathway and inhibiting mevalonate pathway. Cell Signal 2003, I 5:719-727.

10. Fisher JE, Rogers MJ, Halasy JM, Luckman SP, Hughes DE, Masarachia PJ, Wesolowski G, Russell RG, Rodan GA, Reszka AA: Alendronate mechanism of action: geranylgeraniol, an intermediate in the mevalonate pathway, prevents inhibition of osteoclast formation, bone resorption, and kinase activation in vitro. Proc Natl Acad Sci U S A 1999, 96: I33-138.

II. Sawada K, Morishige K, Tahara M, Kawagishi R, Ikebuchi Y, Tasaka K, Murata $Y$ : Alendronate inhibits lysophosphatidic acid-induced migration of human ovarian cancer cells by attenuating the activation of rho. Cancer Res 2002, 62:6015-6020.

12. Denoyelle C, Hong L, Vannier JP, Soria J, Soria C: New insights into the actions of bisphosphonate zoledronic acid in breast cancer cells by dual RhoA-dependent and -independent effects. $\mathrm{Br}$ J Cancer 2003, 88: 1631-1640.

13. Coxon FP, Helfrich MH, Van't Hof R, Sebti S, Ralston SH, Hamilton A Rogers MJ: Protein geranylgeranylation is required for osteoclast formation, function, and survival: inhibition by bisphosphonates and GGTI-298. J Bone Miner Res 2000, I 5:|467-|476.

14. Van Beek ER, Lowik CW, Papapoulos SE: Bisphosphonates suppress bone resorption by a direct effect on early osteoclast precursors without affecting the osteoclastogenic capacity of osteogenic cells: the role of protein geranylgeranylation in the action of nitrogen-containing bisphosphonates on osteoclast precursors. Bone 2002, 30:64-70.

I5. Oades GM, Senaratne SG, Clarke IA, Kirby RS, Colston KW: Nitrogen containing bisphosphonates induce apoptosis and inhibit the mevalonate pathway, impairing Ras membrane localization in prostate cancer cells. J Urol 2003, 170:246-252.

16. Senaratne SG, Mansi JL, Colston KW: The bisphosphonate zoledronic acid impairs Ras membrane [correction of impairs membrane] localisation and induces cytochrome c release in breast cancer cells. Br J Cancer 2002, 86: I479- I 486.

17. Virtanen SS, Vaananen HK, Harkonen PL, Lakkakorpi PT: Alendronate inhibits invasion of $\mathrm{PC}-3$ prostate cancer cells by affecting the mevalonate pathway. Cancer Res 2002, 62:2708-27|4.

18. Saad F: Treatment of bone complications in advanced prostate cancer: rationale for bisphosphonate use and results of a phase III trial with zoledronic acid. Semin Oncol 2002, 29:19-27.

19. Smith MR, McGovern FJ, Zietman AL, Fallon MA, Hayden DL, Schoenfeld DA, Kantoff PW, Finkelstein JS: Pamidronate to prevent bone loss during androgen-deprivation therapy for prostate cancer. N Engl J Med 200I, 345:948-955.

20. Boissier S, Ferreras M, Peyruchaud O, Magnetto S, Ebetino FH, Colombel M, Delmas P, Delaisse JM, Clezardin P: Bisphosphonates inhibit breast and prostate carcinoma cell invasion, an early event in the formation of bone metastases. Cancer Res 2000 , 60:2949-2954.

21. Lee MV, Fong EM, Singer FR, Guenette RS: Bisphosphonate treatment inhibits the growth of prostate cancer cells. Cancer Res 200I, 6 I:2602-2608.

22. Lerner EC, Qian Y, Blaskovich MA, Fossum RD, Vogt A, Sun J, Cox AD, Der C], Hamilton AD, Sebti SM: Ras CAAX peptidomimetic FTI-277 selectively blocks oncogenic Ras signaling by inducing cytoplasmic accumulation of inactive Ras-Raf complexes. J Biol Chem 1995, 270:26802-26806.

23. McGuire TF, Qian Y, Vogt A, Hamilton AD, Sebti SM: Plateletderived growth factor receptor tyrosine phosphorylation requires protein geranylgeranylation but not farnesylation. J Biol Chem 1996, 27 I:27402-27407.

24. Cussenot O, Berthon P, Berger R, Mowszowicz I, Faille A, Hojman F Teillac $P$, Le Duc A, Calvo F: Immortalization of human adult normal prostatic epithelial cells by liposomes containing large T-SV40 gene. J Urol I991, | 46:88|-886.

25. Skehan P, Storeng R, Scudiero D, Monks A, McMahon J, Vistica D, Warren JT, Bokesch H, Kenney S, Boyd MR: New colorimetric cytotoxicity assay for anticancer-drug screening. J Natl Cancer Inst 1990, 82: I I07-IIII.

26. Awad AB, Williams H, Fink CS: Effect of phytosterols on cholesterol metabolism and MAP kinase in MDA-MB-23 I human breast cancer cells. J Nutr Biochem 2003, I 4: I I I-I I9.

27. Corey E, Brown LG, Quinn JE, Poot M, Roudier MP, Higano CS, Vessella RL: Zoledronic acid exhibits inhibitory effects on osteoblastic and osteolytic metastases of prostate cancer. Clin Cancer Res 2003, 9:295-306.

28. Crick DC, Andres DA, Waechter CJ: Novel salvage pathway utilizing farnesol and geranylgeraniol for protein isoprenylation. Biochem Biophys Res Commun 1997, 237:483-487.

29. Lobell RB, Liu D, Buser CA, Davide JP, DePuy E, Hamilton K, Koblan KS, Lee Y, Mosser S, Motzel SL, Abbruzzese JL, Fuchs CS, Rowinsky EK, Rubin EH, Sharma S, Deutsch PJ, Mazina KE, Morrison BW, Wildonger L, Yao SL, Kohl NE: Preclinical and clinical pharmacodynamic assessment of L-778,I23, a dual inhibitor of 
farnesyl:protein transferase and geranylgeranyl:protein transferase type-I. Mol Cancer Ther 2002, I:747-758.

30. Holstein SA, Cermak DM, Wiemer DF, Lewis K, Hohl RJ: Phosphonate and bisphosphonate analogues of farnesyl pyrophosphate as potential inhibitors of farnesyl protein transferase. Bioorg Med Chem 1998, 6:687-694.

3I. Ownby SE, Hohl RJ: Isoprenoid alcohols restore protein isoprenylation in a time-dependent manner independent of protein synthesis. Lipids 2003, 38:75I-759.

32. Allal C, Favre G, Couderc B, Salicio S, Sixou S, Hamilton AD, Sebti SM, Lajoie-Mazenc I, Pradines A: RhoA prenylation is required for promotion of cell growth and transformation and cytoskeleton organization but not for induction of serum response element transcription. J Biol Chem 2000, 275:3 I00I-31008.

33. Dunford JE, Thompson K, Coxon FP, Luckman SP, Hahn FM, Poulter $C D$, Ebetino FH, Rogers MJ: Structure-activity relationships for inhibition of farnesyl diphosphate synthase in vitro and inhibition of bone resorption in vivo by nitrogen-containing bisphosphonates. J Pharmacol Exp Ther 200I, 296:235-242.

34. Fisher JE, Rodan GA, Reszka AA: In vivo effects of bisphosphonates on the osteoclast mevalonate pathway. Endocrinology 2000, I 1 1:4793-4796.

\section{Pre-publication history}

The pre-publication history for this paper can be accessed here:

http://www.biomedcentral.com/1471-2407/6/60/prepub

Publish with Biomed Central and every scientist can read your work free of charge

"BioMed Central will be the most significant development for disseminating the results of biomedical research in our lifetime. "

Sir Paul Nurse, Cancer Research UK

Your research papers will be:

- available free of charge to the entire biomedical community

- peer reviewed and published immediately upon acceptance

- cited in PubMed and archived on PubMed Central

- yours - you keep the copyright 